\title{
EDITORIAL
}

\section{In This Issue: Working in Community and Improving Health Care Quality}

\author{
Kurt C. Stange, $M D, P b D$, Editor \\ Ann Fam Med 2013;11:498-499. doi:10.1370/afm.1603.
}

$\mathrm{A}$ rticles in this issue of Annals cluster into 2 themes. The first elucidates the process and outcome of people working together in community. The second helps us to differently understand quality in health care.

\section{COMMUNITY}

The High Plains Research Network and their Community Advisory Council use a community-based participatory research (CBPR) approach to develop a multicomponent intervention to increase colon cancer screening, as well as to compare colon cancer screening in 9 intervention counties in northeast Colorado with 7 counties in southeast Colorado. ${ }^{1}$ An essay by the same Community Advisory Council' reveals the CBPR process through the voices of participants. A compelling accompanying video (www.annfammed.

org/content/11/6/568/suppl/DC1) brings their

voices and insights to life.

Researchers from PRIME Net, a consortium of practice-based research networks focused on generating relevant new knowledge among traditionally underrepresented and underserved populations, use a sequential combination of key informant interviews and focus groups to discover stages in a "cycle of trust" that can be developed in recruiting and retaining underrepresented populations for practice-based research network studies. Flexible strategies at each stage, as well as close engagement of practice and community partners, develop trust and ongoing participation. ${ }^{3}$

Hurricane Sandy provides an opportunity for a local pharmacist to facilitate, experience, and rediscover the meaning of community in Hoboken, New Jersey. ${ }^{4}$

\section{QUALITY}

Patients seen in US federally qualified community health centers generally report high quality of care, according to data from a nationally representative survey reported by Lebrun-Harris and colleagues. ${ }^{5}$
Access to care and patient-centered communication are strongly associated with reports of overall quality.

Across the globe in China, Wang and colleagues ${ }^{6}$ assess the association of primary care attributes with whether community health centers are government owned and managed and whether they are managed by hospitals or by private and social entities. They found better patient-reported first-contact care and coordination of care for government-owned and -managed centers.

Two articles-a methodologically sophisticated study and an essay-advance knowledge of the multifactorial nature of health care quality and how factors affecting it can be understood and measured. The Work Relationships Scale, newly developed and validated in a study by Finley et al, shows the quality of work relationships to be reflected in patient quality ratings for individual clinicians and for the overall quality of health care. ${ }^{7}$ The essay by Loxterkamp explores the effect of health care expectations. He identifies 6 habits of mind and practice that his experience finds are associated with "healthier, happier encounters with patients and their illness." 8 This essay is an Annals Journal Club selection, as we apply Loxterkamp's concepts of identity, listening, touching, looking, planning, and follow-up to a study in this issue described below. The essay provides a frame for reflecting on the interpretation and application of Darlow's study of the impact of what we say to people with low back pain.

Darlow et al's study, a second Annals Journal Club selection, shows the need for us to be mindful of what we say to patients with low back pain. ${ }^{9}$ Mindfulness in practice was a theme of the last (September/October 2013) issue of Annals, and this specific application further reflects that theme. Despite patients looking for information on the Internet and from family and friends, health care professionals are found to have the strongest effects on patients' beliefs and attitudes, with messages to protect the back having long-term negative effects and messages of reassurance and encouragement of activity having long-term positive effects. 
A new conceptualization and measure of the impact of information from electronic knowledge resources is articulated and evaluated by Pluye et al as the "number needed to benefit from information" - the number of patients for whom clinical information is retrieved for one patient to benefit. ${ }^{10}$

The burden of multiple chronic conditions among patients see in primary care practice is shown in an article by Brett et al. ${ }^{11}$

We welcome your reflections at www.AnnFamMed. org.

\section{References}

1. Westfall JM, Zittleman L, Sutter $C$, et al. Testing to prevent colon cancer: results from a rural community intervention. Ann Fam Med. 2013;11(6):500-507.

2. Norman N, Cowart S, Felzien M, et al. Testing to prevent colon cancer: how rural community members took on a community-based intervention. Ann Fam Med. 2013;11(6):568-570.

3. Getrich CM, Sussman AL, Campbell-Voytal K, et al. Cultivating a cycle of trust with diverse communities in practice-based research: a report from PRIME Net. Ann Fam Med. 2013;11(6):550-558.
4. See S. Rediscovering community-reflections after Hurricane Sandy. Ann Fam Med. 2013;11(6):571-573.

5. Lebrun-Harris LA, Shi L, Zhu J, Burke MT, Sripipatana A, NgoMetzger Q. Effects of patient-centered medical home attributes on patients' perceptions of quality in federally supported health centers. Ann Fam Med. 2013;11(6):508-516.

6. Wang HHX, Wong SYS, Wong MCS, et al. Patients' experiences in different models of community health centers in southern China. Ann Fam Med. 2013;11(6):517-526.

7. Finley EP, Pugh JA, Lanham HJ, et al. Relationship quality and patient-assessed quality of care in VA primary care clinics: development and validation of the Work Relationships Scale. Ann Fam Med. 2013;11(6):543-549

8. Loxterkamp D. What do you expect from a doctor? Six habits for healthier patient encounters. Ann Fam Med. 2013;11(6):574-576.

9. Darlow B, Dowell A, Baxter GD, Mathieson F, Perry M, Dean S. The enduring impact of what we say to people with low back pain. Ann Fam Med. 2013;11(6):527-534.

10. Pluye P, Grad RM, Johnson-Lafleur J, et al. Number Needed to Benefit from Information (NNBI): proposal from a mixed methods research study with practicing family physicians. Ann Fam Med. 2013;11(6): 559-567.

11. Brett T, Arnold-Reed DE, Popescu A, et al. Multimorbidity in patients attending 2 Australian primary care practices. Ann Fam Med. 2013;11(6):535-542

\section{CHANCE-OF-ADDRESS FORM

Please complete this form and mail to the following address or fax to Annals Circulation at 913-906-6080:

Annals of Family Medicine, Circulation Department, 11400 Tomahawk Creek Pkwy, Leawood, KS 66211-2680

Check if member of sponsoring organization:

$\begin{array}{ll}\square \text { AAFP } & \square \text { ABFM } \square \text { STFM } \square \text { ADFM } \\ \square \text { AFMRD } \square \text { NAPCRG } \square \text { CFPC }\end{array}$

ID number from label on your journal cover

OLD Information (Please print.)

\begin{tabular}{ll}
\hline Name \\
\hline Company (if applicable) \\
\hline Address (Street plus Apt or Ste) \\
\hline City & Postal Code (9-digit ZIP for US) \\
\hline Country & Fax \\
\hline Telephone & \\
\hline E-Mail & \\
\hline
\end{tabular}

NEW Information (Please print.)

\begin{tabular}{|c|c|}
\hline Name & \\
\hline Company ( & \\
\hline Address (S & \\
\hline City & State \\
\hline Country & Postal Code (9-digit ZIP for US) \\
\hline Telephone & Fax \\
\hline
\end{tabular}

